\title{
Aberrations in the Heartland. An interview with Rachel Chavkin, Artistic Director of T.E.A.M.
}

\section{Fabienne Collignon}

\section{(2) OpenEdition \\ Journals}

Electronic version

URL: https://journals.openedition.org/ejas/2123

DOI: $10.4000 /$ ejas.2123

ISSN: 1991-9336

Publisher

European Association for American Studies

\section{Electronic reference}

Fabienne Collignon, "Aberrations in the Heartland. An interview with Rachel Chavkin, Artistic Director of T.E.A.M.", European journal of American studies [Online], 3-1 | 2008, document 4, Online since 02 April 2008, connection on 08 July 2021. URL: http://journals.openedition.org/ejas/2123 ; DOI: https:// doi.org/10.4000/ejas. 2123

This text was automatically generated on 8 July 2021.

Creative Commons License 


\title{
Aberrations in the Heartland. An interview with Rachel Chavkin, Artistic Director of T.E.A.M.
}

\author{
Fabienne Collignon
}

1 The interview took place at Battersea Arts Centre (BAC), London, on the $7^{\text {th }}$ of September, 2006. Many thanks to Rachel Chavkin for her kindness and intellectual generosity.

2 T.E.A.M., Theatre of the Emerging American Moment, is a New York-based theatre company that, according to their website, "pairs rigorous physicality with heightened text to dissect and celebrate the experience of living in the world today" (http:// www.theteamplays.com/). Their most recent performance, a brilliantly jumbled piece called Particularly in the Heartland, was presented at the Edinburgh Fringe Festival in the summer of 2006, an event that, last year exceptionally, was steeped in direct, immediate political analysis: a great deal of the best theatrical works there were orbiting around issues of wreckages. Existing as a part in a much larger set of relations - defined through preoccupations with the real, with inventions and disinformation, with distorted plot structures, disasters, violence and terror - Particularly in the Heartland, in terms of its subject matter, as well as its point of departure, is, indeed, a meditation on conflict. In the opening moments, an unspecified act of intervention - a tornado, or another such fierce weather phenomenon, the second coming of Christ, an alien abduction - leaves the Springer kids alone on their isolated farm in Kansas. A number of intruders appear: Tracy Jo, by all accounts a pregnant alien sent on a reconnaissance mission from Mars; Bobby Kennedy, who is being dug up in the yard, instead of dinosaur bones, and Dorothy, a New York business executive with pink slippers who falls out of the sky into the cornfields. The company's website asks:

What if Robert F. Kennedy had survived the assassination in 1968? Why would the citizens who are most harmed by the United States' current domestic policies empower their government further? What happens when outsiders are allowed in? How will they 
change the people with whom they live, and how will they themselves be changed? (http://www.theteamplays.com/).

5 As is so often the case, the figure of a Kennedy manifests a body of thought haunted by what might have been, a perpetually unknown entity signifying the politics of possibility. John F Kennedy's ghostly presence appears in T.E.A.M.'s previous work, a much more unraveled, agonized play called A Thousand Natural Shocks. However, the assassination of Bobby Kennedy, a recurring sore matter also reflected on by Emilio Estevez in his recent film Bobby, implies, yet also entails, more so than his brother's execution, a veritable decline and despair accompanied by constrictions and dead ends; the Ambassador Hotel's stainless steel kitchen, where Senator Kennedy is shot, seems a configuration of the iron grips of the Cold War. The setting of his resurrection is itself rich in oddities: a square contains the Kansan terrain and serves as symbol and concentration, in the geographical centre of the country, of the spirit of America. A "stand-in for the nation as a whole, a distilled essence" of the US, as Thomas Frank notes, the lonely stretches of Kansas, a "freak state," violent and radical (Thomas 29, 31) - it was, after all, settled by abolitionists to prevent Missouri, a slave state, from extending its territory - work well as the location for a play that claims to "[look] at what is right, what is wrong, and what might be in America's heartland" (http:// www.theteamplays.com/).

6 As an intellectual endeavor, however, Particularly in the Heartland does not seek to accuse or cast blame onto geography, though it certainly interrogates its intricate, frequently unconscious, effects on the psyche. Space, of course, as Anthony Vidler writes, "is not empty, but full of disturbing objects and forms" (vii); outside perceptions of Kansas are uneasy, troubled projections that concern themselves with terrors of normality and narrowness of vision. As such, the state behaves as a topography of despair, a conduct traced to both reality and presumption; its economic deterioration, a result of the brutal processes of a profit-maximizing, industrialized agriculture, exhausting the land and its people, surely develops readings of the Kansan landscape as forlorn. Its propensity to emit anxiety, if not horror, as a response to its terrifying void, in addition to its considerable literary and filmic baggage (The Wizard of $\mathrm{Oz}$, of course, and Truman Capote's In Cold Blood, for example) thus inspire a narrative of inspection that uses, transforms and transgresses the premises of its origins.

7 It is worth noting here that rather than being didactic or closed in form, the style of Particularly in the Heartland style is wild and wide-open, spilling out of the circumscribed area of the stage and into the seating banks: it diverges greatly from other shows, say National Theatre of Scotland's Blackwatch, because it chooses to lose touch with the ground. Graphic realism is absent here; instead, the piece integrates fantasy and reality, a juxtaposition that causes no incompatible discords but fertile results as it puts considerable emphasis on inspired resolutions of problems as much as on the crises themselves. Thus, the concerns of the play - the lack of understanding relating to the unambiguous re-election of George W Bush, his popularity in the "heartland," that tumultuous inner sea of red embracing so much complex dissatisfaction, the debates concentrating on vaguer, more ephemeral matters, such as the nature and direction of America and the implementation of goodness and decency become discussions whose exceptional registers arrive at the resurrection of what was lost and, importantly, of what remains possible. 
Thus, considering that the vast, flat plains of Kansas are especially suited to aesthetic wanderings merging ground and horizon, thereby creating a curious perspective, defined as warped and eerie and almost infinite in its monotony and distances - the early colonists frequently got lost, experienced mirages and hallucinations - its weird environment evidently is a magnet attracting all sorts of shapes. The emergence of the cases featured here, the outlandish, the murdered, the fictional, truly forming a "freak state," are grounds of celebration more than despondency: the level plains - soil in American thought has, after all, always functioned as a singular area whose regenerative powers have been affirmed since the nation's invention - and immense sky contain buried secrets that might well prove to be material for a solution.

10 Q: You used the ghost of Bobby Kennedy - would you say that this is an apt metaphor for the way that the economic and political awareness in Kansas have become ghostly? There's this lack of understanding [between cause and effect]; social issues seem to be more relevant than the economic ones despite the fact that a majority of these people live in poverty and then you have the figure of Bobby Kennedy who is generally seen as -

R. CHAVKIN: - a liberal, as a figure who is able to operate at grassroots levels, in the way that the churches are operating now, and who was an incredible galvanizing force in a time of major hope and despair in America. I mean the late 1960s in America were a mess in terms of polarization in the country, people just screaming at each other basically, and so yes, he is the ghost of himself, but he is also the ghost of an America that's been lost at a time when change was possible. Hope and the belief in a political revolution to take care of the "common man" is one of the things that define Kennedy and ultimately he was most beloved by black America because he was one of the first major white politicians in support of the civil rights movement - he was the champion of the disenfranchised. Before he began running for President, he took these major trips into really rural Kentucky, into the forests of the poor rural areas, but also into the Bronx in New York City and was looking at this extreme poverty and basically saying, "this poverty shows a spiritual poverty in America," and so he's the ghost of everything that's been lost. And when we're getting to this big Christmas Carol section at the end [of the play], we talk about him being essentially the ghost of an America past.

12 Q: It makes sense to pick Bobby rather than John F. Kennedy, who didn't have this rapport with the "common man".

13 R.C.: I mean John was an absolutely stunning President, he was everything that one would want from a President: he was good-looking, he had a beautiful wife and his reign of a thousand days before he was killed are referred to as "Camelot" in America, so he gets associated with this immediate post-war idyllic Levittown, and the idea of the veterans coming home and starting families and the space race and all that, and so what's happening is this growing age which actually ends up creating the Vietnam war, the Cold War, the Korean war, so there is actually a lot of rotten stuff underneath [the image of JFK]. But I think that when people think of John F. Kennedy, rather than thinking politics, it's more the sort of age that he's associated with, whereas Bobby Kennedy ultimately did have tremendous ideology and tremendous political currency of his own that he was really forging ahead and was trying to fight for actual major change. John F Kennedy was the creation and embracing of a status quo, of "every man 
deserves a wife and a home," he starts the Peace Corps, but it's not a decidedly ideological movement that Jack Kennedy is associated with.

Q: Bobby Kennedy is being dug up, rather than falling from the sky. Anna [Kristen Sieh] talks about the origin of Kansas as a sea, and the sea is often a symbol for the unconscious. Is this theory - of Kansas as marine in origin - a fact?

R.C.: Yes. In prehistoric times, 65 million years ago, what is North America now actually existed as two separate continents, and they think that the end of the dinosaur age came when a meteor struck the earth and that this meteor most likely struck between the two continents that were North America and essentially brought them crashing together. The meteor struck in the middle of that sea, now called the inland sea, that room between the two continents, and forged, folded them into each other to become one continent. So Kansas actually has some of the biggest dig-sites for dinosaur research in the country. There's this book called The Oceans of Kansas [Bloomington: University of Indiana Press, 2005], which is a science textbook and it's about the dinosaurs that were living in Kansas and there's also a book called The Eternal Frontier, by Tim Flannery [London: Vintage,2002], which was a big resource for us. The subtitle is An Ecological History of North America, and the book opens with a discussion of this 65 million year-old disaster that forged the continent.

\section{Q: How much is the play based on The Wizard of Oz?}

R.C.: We watched The Wizard of $\mathrm{Oz}$ a lot, and talked about it a lot when we were in the earlier stages of the show, but ultimately I think it's actually based very little on it. I mean, we picked the character Dorothy and we've got the ruby slippers, and we spoke about the image of rather than the character called Dorothy being Dorothy, but of the kids as Dorothy and their house getting picked up by a tornado and she lands in the house and it is still black and white until she goes outside and then the world goes into technicolor, and so we talked about how to do black and white on stage and how to slowly bring color in as the new family is formed. But I think other than the fact that our play is obviously a fantasy as well, there's very little. I mean, there are a bunch of different parallels; we talked about the parallel between the wizard in $\mathrm{Oz}$ and Robert, and this idea, in the actual book - it's not done in the movie - but in the books, Frank L Baum's wizard of Oz makes everyone wear green glasses, so that Emerald City isn't actually green at all, it's just everyone's wearing green glasses and there's a moment when they take off their glasses and it's like "oh my God, this place is concrete and stone," so we were talking about our Thanksgiving being the moment when everyone takes off their green glasses, when everyone's happy and everyone's getting along and then suddenly you kind of stutter and realize that there are huge ideological differences between the people that are living in the house that we haven't even begun to address yet.

Q: What other ideas did you use? Did you use any other texts specifically in relation to Kansas?

R.C.: We all read a lot about Kansas, of course, and we looked at King Lear a little bit and the idea of America as Lear and going insane in the middle of a storm. That's I think at this point not very visible in the actual play. The Eternal Frontier, which I mentioned earlier, was a big inspiration for us, and we have a little text taken from that. And then there's the Bible. We used the Bible a lot. We're all carrying copies of the Bible. And then the other main thing we got into are the books from the Left Behind series, which are one of the top-selling fiction series in the United States and are the fictionalization of the Revelation. They're intense and terrifying and written like trashy romance 
novels; the writing is terrible and they're not so much just bad but also uninformed, like there's a sentence that says "the Middle Eastern countries of Ethiopia and Libya", and you're like, "oh my God that's Africa", but the issue is that [such statements] are taken for fact, they're taken to be incredibly informed. There's this sense, particularly with news in America, this idea that if something's written in the paper it must be true; there's this lack of skepticism. We felt really bad paying money for the books, so we got one copy and passed it around, but we had to look at those because they are the bestselling fiction in that area, and at a certain point you have to kind of let yourself mock them, but at a certain point you also have to take them seriously, because they are dictating the beliefs of millions of people and are one of the main reasons why in the United States just now environmental reform is having such a hard time. If you believe that you're living in the end time, then why be worried about greenhouse emissions building up over the next fifty years? So those were the main things we looked at.

R.C.: The play originally started with general ideas about space and how where you grow up shapes your brain and your perception of reality. It came up because Jake, who plays Robert F. Kennedy, grew up in California, and has this very expansive sense of space, is much slower-moving than I am - I'm East Coast so I'm constantly moving - so it's about that, and then at the Fringe last summer, when we were there in 2005, I read this article in the New York Times online that was about this bankruptcy legislation that Bush had signed in April and would actually go into effect in October 2005, and it basically made declaring bankruptcy impossible in the United States. You know, declaring bankruptcy is an incredibly painful process, but it's sort of the truest process of getting to start again, like kind of getting to be reborn, just as a social individual with no credit, but also not suffering under debt. When we read that article it said that as people were trying to beat the October deadline, bankruptcy filings had skyrocketed, "particularly in the heartland." So that's exactly what Thomas Frank's book is about, it's about the people most hurt by Bush's policies and who, despite this, are the ones who are his greatest supporters. So it's sort of this contradiction of that [that lies at the heart of the play]. We didn't want to make a piece mocking the Midwest; it's trying to understand what the gap is in getting that cause and effect, in "why can't you see that?" We talked a lot about these ideas of fear and isolation, and the fact that you're in the centre of the country but you're so far away from all of the places that are the cultural, artistic and intellectual bases and so you have this swath of America that basically receives nothing but mass-produced things. All the restaurants are chains, you have Wal-Mart determining what you're going to read and Wal-Mart doesn't sell certain books, they just don't, and because they're not even getting the news that says there's other stuff out there, they're not even aware of how uninformed they are - it's again a lack of skepticism about your sources - and so we just became very interested in what was going on there, of what could possibly be going on. When Robert takes Todd by the shoulders and says, "What are you thinking?", that for us is just us saying that at a certain point we have no idea, as liberal New Yorkers, probably arrogant, I don't have a clue what people could be understanding that they would elect Bush again in 2004. Q: So the concept of "heartland," what does it mean to you? R.C.: (laughter) I'm laughing because there's a whole monologue that was cut from the show that I wrote as one of the first pieces of text that we ever worked with, and it was 
supposed to be spoken by the alien, Tracy Jo, in part of her research for coming down. The first thing I often do when starting to write a play is go to dictionary.com and the first line of the monologue was, "dictionary.com describes it as a noun; I think of it more as a state of mind". For us, it's totally a mythological thing, it is this idea of the red-blooded American, and even that is a pun because red is of course being associated with conservatism, and the fact that after 2000 and 2004 you see those maps where the coasts are blue and the centre is red, and the pun is so obvious at this point that it's being taken for granted that that is the "heartland". I have this idea of burrowing into the body and we talked about the idea of heart disease, heart failure, certainly the heart being the source of patriotism and belief; the idea that these are the people who are most patriotic, who love America the most, and then who are destroying it the most. So there's this idea of a diseased heart trying to pump blood through its body but not necessarily succeeding in that task, because there are holes and because it is rotting. So those are the images that we talked about in relation to the term "heartland" and we just decided to set it in Kansas because Kansas has some stuff that comes with it, the Wizard of $\mathrm{Oz}$, the fact that it is the geographical centre of the United States, the fact that it's flatter than a pancake, scientifically proven...

Q: In his book The Great Plains, published in 1931, the author Walter Prescott Webb quotes people who describe the region as "ocean-like in its monotony," which brings with it the idea of being lost at sea and drowning, an image that, to a certain extent, returns in Truman Capote's In Cold Blood.

R.C.: Two of our cast members are reading that book just now .... There's just so much stuff that dies, so many things that are cut from the play - I bring this up because Sarah originally had this whole monologue about being lost at sea, saying the lines, "where's my boat, where's my boat?" and talking about the fact that her ancestors came over in ships. Ultimately, the question always is, "does the audience know this already and do we need to be telling them again," because we're doing the play on an assumption that many of our audience members have at least heard of the book What's the Matter With Kansas and many of them have read about mega-churches, so how do we use this stuff not to teach but to actually talk about the more abstract aspects of questions that the newspapers can't talk about. What What's the Matter With Kansas can't discuss is the sort of more intangible things that pass between human beings. One of the things I still don't know is if we've helped people draw these connections or not.

$\mathrm{Q}$ : While you were talking about the heart and its deficiencies, I thought about one of your last year productions at the Fringe, A Thousand Natural Shocks, based on Hamlet, and, obviously, the recurring rottenness at the core of America, that time traced back to the JFK assassination.

R.C.: That's something that clearly continues to obsess us, this idea of thinking things are ok and clearly they're not ok; that you go through life on a daily basis and life continues and so its fine but that there's clearly something very wrong with what's happening.

28 Q: Have you read some of Ray Bradbury's short stories? (R.C.: Yes) I'm bringing this up because he talks a lot about the similarities between Mars and the Midwest, that the first people to colonize Mars are those "men accustomed to spaces and coldness and being alone", and in $\mathrm{Oz}$ there is also this idea that that region lies behind the moon and that Kansas is the name of the star from which Dorothy fell.

R.C.: There is a writer named Mac Wellman, he's a crazy avant-garde playwright and poet who began writing in the Eighties and is still working now, very bizarre writing 
and I love him, and he's from Cleveland, Ohio, but he has a very similar thing to Bradbury in terms of these major Midwestern scenes that then erupt with alien mores and time-jumping between Mars and the Midwest. To a certain extent there's this feeling about the mega-churches and the Left Behind books, that they're so bizarre that you couldn't make it up. It is also like this in Wellman's writing - he has a novel called Annie Salem, which is absolutely gorgeous, about this young teenager who turns out is a 2000-year-old Martian and it jumps back and forth all over the place. It's actually kind of heart-breaking because the book starts with him being in the woods by his house and he takes a nap, night falls, and he wakes up to this primitive chanting sound and he describes what he's seeing and then finally there's this alien orgy of violence and ultimately what you realize is that he's watching a Ku Klux Klan meeting in the woods. So there is this sense that under a certain light, in a certain moonbeam or something, the things that are alive in the Midwest, the remaining racism, the xenophobia, the simplicity, the pioneer spirit, all of these things do have a certain alien quality to them. I think it makes so much sense, these ideas of the parallels between space and then the actual space of the Midwest - there's so much space in Kansas. And Libby, who plays Sarah, when she has that question period in the middle of the show, is often asked, "why do you like living in Kansas?", and she talks about how at night there's so much space that you can actually see the curvature of the earth. So it is kind of like being on another planet, or moon walking.

Q: Stephen King's Children of the Corn, despite being set in Nebraska, also delves into this idea of things going horribly wrong and the rest of the world remaining unaware... Your own play, however, is still really optimistic.

R.C.: Yes. All of us as artists came of age in such a post-modern time where every gesture was so laden with irony and it was impossible to almost even finish a sentence because before you got there, you'd want to say, "well, somebody's already said this before," and so it's us kind of trying to push against that, or really push through that, to get to somewhere else that is a place where change is possible. I think ultimately that for us, you know we got back and forth on whether we're making not political theatre but what kind of political theatre it is that we're making, and the fact that we're not making direct action theatre in any way but that it's our responsibility that if we're talking about problems in the country to make clear that there are possibilities for change. We're probably never going to offer the answer to what that change is, but there has to be that possibility of hope, even if it just continues to boil down to the fact that we're all human - in ... Heartland we all like glitter and snow, I mean the play aggressively engages in these really child-like images to try to restore that sense of jubilance and joy and that there is a hope that people on all sides will come to their sense a little bit and try to begin talking again - dialogue has just become calcified in the country.

$\mathrm{Q}$ : And do we need these dead politicians?

R.C.: We joked about that fact that we shoot Bobby Kennedy when he comes up out of the ground, and we talked about the fact that if our savior came back now, would we recognize him? I don't mean savior in the Jesus-sense, although maybe to a certain extent I do, who knows, but ultimately I kind of do think we need a miracle. We need something because of what these churches have done to the country, and it's not just the churches, I don't necessarily even mean religion, but what these men running the 
churches have done, and what some of the politicians and pundits both on the left and right have done and who are as ghastly and selfish and stubborn as anything you could ever dream, who have reduced almost everyone to the stage of being like a wounded animal, so that you have to go into every conversation waving a white flag, saying, "I'm not going to attack you" and then maybe after a year or so, people might trust you that you're not going to attack their way of life. What the Republican party has done ingenuously and devastatingly is that it's not just a disagreement about political ideas, it's a challenge to your way of life, and terrorists are challenging the American way of life, Democrats are challenging the conservative and religious way of life, and when you frame the question that way it becomes incredibly hard to recover and say, "really, I think that welfare is important." Because those things have become so inextricably linked to this inflexibility and to this idea that it is "my way, or the highway," and so we've come to a standstill.

I think it would be awesome if Bobby Kennedy actually came up out of the ground.

\section{BIBLIOGRAPHY}

\section{Works Cited}

Frank, Thomas. What's the Matter With Kansas? How Conservatives Won the Heart of America: New York: Henry Holt \& Company, 2004.

Vidler, Anthony. 'Preface.' Warped Space: Art, Architecture and Anxiety in Modern Culture. Cambridge, MA \& London: MIT Press, 2001, vii-ix.

Internet site : http://www.theteamplays.com Accessed on October 20, 2006.

INDEX

Keywords: Chavkin, Rachel, T.E.A.M, Kansas, The Kennedys, American politics, Megachurches, (Outer) Space.

\section{AUTHOR}

\section{FABIENNE COLLIGNON}

University of Glasgow 